\title{
Revised chrono-biostratigraphy of Lower Miocene deposits of the Eastern Mediterranean (SW Turkey), based on calcareous nannofossils
}

\author{
Gülin Yavuzlar* and Enis Kemal Sagular \\ Suleyman Demirel University, Faculty of Engineering, Departament of Geological Engineering, West Campus, Cunur, TR32260 Isparta, Turkey; \\ (corresponding author: gulinyavuzlar@gmail.com, eniskemal@gmail.com)
}

doi: $10.4154 / g c .2018 .15$

Crossre Simlarty ched

Article history:

Manuscript received January 08, 2018

Revised manuscript accepted July 16, 2018

Available online October 17, 2018

\begin{abstract}
Lower Miocene deposits of the Güneyce Formation formerly described as the Elmalı Formation of Lutetian-Burdigalian age are located near the villages of Gökçebağ (Burdur) and Yakaören (Isparta), (southwestern Turkey), Eastern Mediterranean, and overlie the pre-Neogene tectonostratigraphic units of the Isparta Angle. The purpose of this study is to discuss new biostratigraphic data calibrated to originally classified nannofossil records. Three Early Miocene nannofossil biozones, NN1 - Triquetrorhabdulus carinatus Zone, NN2 - Discoaster druggii Zone and NN3 - Sphenolithus belemnos Zone, were defined in clastic sediments of the Güneyce Formation. In addition, one Lutetian biozone, NP16 - Discoaster tanii nodifer Zone, was recognized in the remaining outcrops of the Isparta Formation unconformably underlying the Güneyce Formation.

Nannofossil assemblages of shallow marine deposits in the Güneyce Formation contain high amounts of reworked (Palaeogene and Cretaceous) specimens. New biostratigraphic data and sedimentary features of the Güneyce Formation clastics indicate shallow marine deposition and the beginning of the transgression, spreading over an erosional surface on the ophiolitic melange and Cretaceous to Eocene marine successions rising to the west of the region.
\end{abstract}

Keywords: Aquitanian, Burdigalian, biostratigraphy, calcareous nannofossils, marine deposits, geologic map structural constructions related to the study area. The accepted former (and common) view is that the Eocene marine sedimentary successions (Elmalı Formation) were overthrust by the ophiolitic melange (Gökçebağ Melange) after the Early Miocene (Fig. 1). However, the results of this study show that there are two angular unconformable marine successions, the Isparta Formation (Lutetian) and the Güneyce Formation (Early Miocene), overlying the ophiolitic melange (Fig. 2). In the region, the Yavuz Flysch (GUTNIC et al., 1979), was described as marine carbonate and clastics deposited during the Paleocene to Eocene (Lutetian interval) and the second succession, the Elmalı Formation (ŞENEL, 1997), was described as marine shelf clastics deposited during the Lutetian or ranging from the Lutetian to the Burdigalian. According to GÖRMÜŞ et al. (2001), the studied Güneyce Formation comprises six lithological units from the bottom to the top: (1) mudstone dominated facies (muddy facies); (2) sandstone dominated facies (sandy facies); (3) olistostrome facies; (4a) rhythmic sandstone-mudstone facies; (4b) carbonate facies; (5) sandstone facies and (6) coarse clastics-conglomerates facies. In this area, there are particularly clastic facies 1 to $4 \mathrm{a}$. The overlying units of the investigated area are Plio-Quaternary volcanics and Quaternary alluvium or colluvial fan deposits.

\section{MATERIAL AND METHODS}

In this study, 35 samples of various grain-sized clastic or carbonate rocks such as marls, mudstones, sandstones or limestones were collected and examined from 17 locations within the three measured stratigraphic sections. All the study material obtained from YAVUZLAR (2015) is preserved in the General Geology Laboratory of Suleyman Demirel University. The three stratigraphic sections, Necibin Tepe, Arapdere and Abidinoğlutaşı Tepe

were researched in the field (Fig. 3). The sedimentary succession

\section{GEOLOGICAL SETTING}

There are two different geological interpretations on the stratigraphy of the Palaeogene and Neogene marine sequences and their 


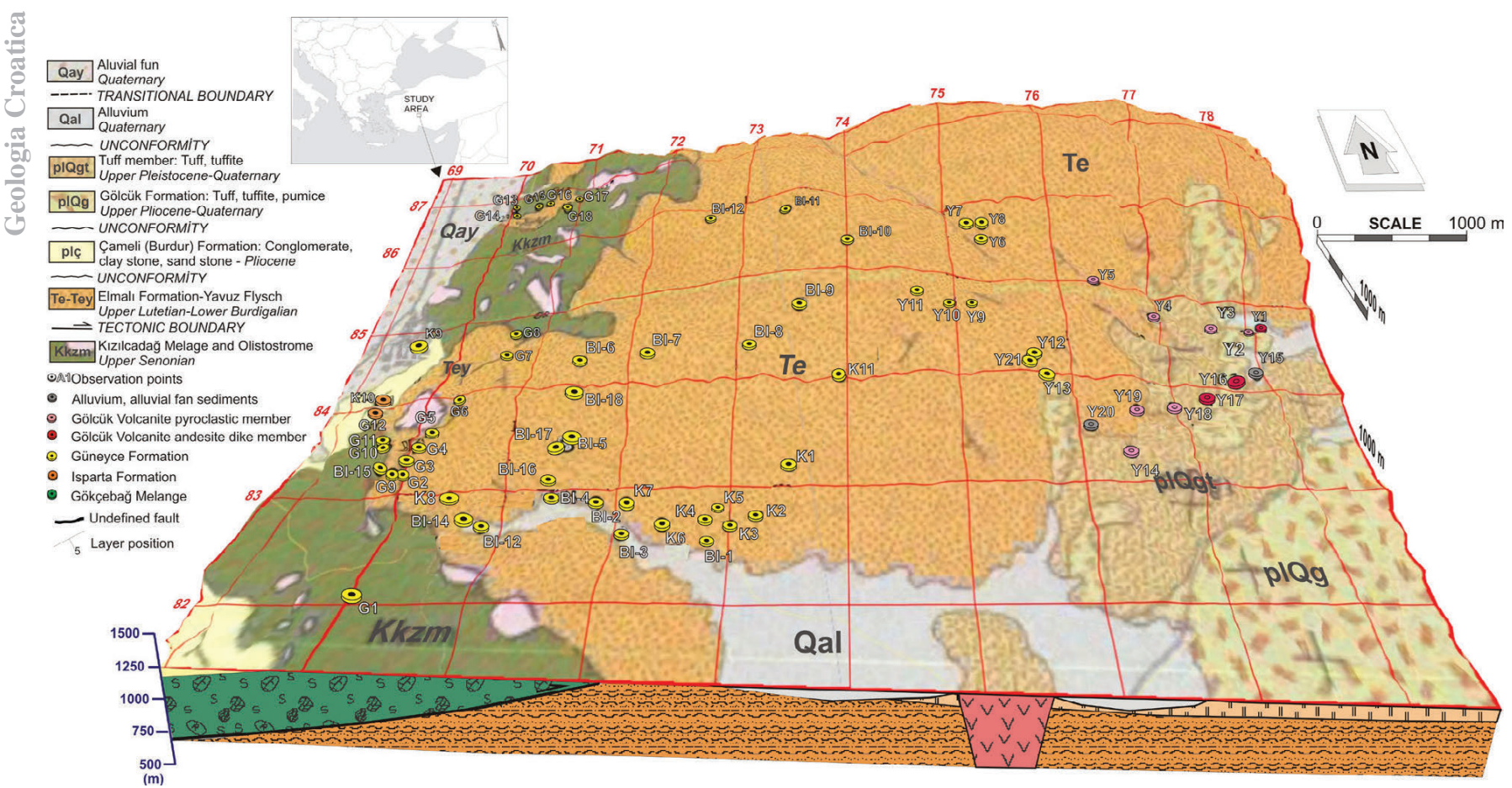

Figure 1. A new detailed version of the map, built on the existing geologic maps (GUTNIC et al., 1979, ŞENEL, 1997).

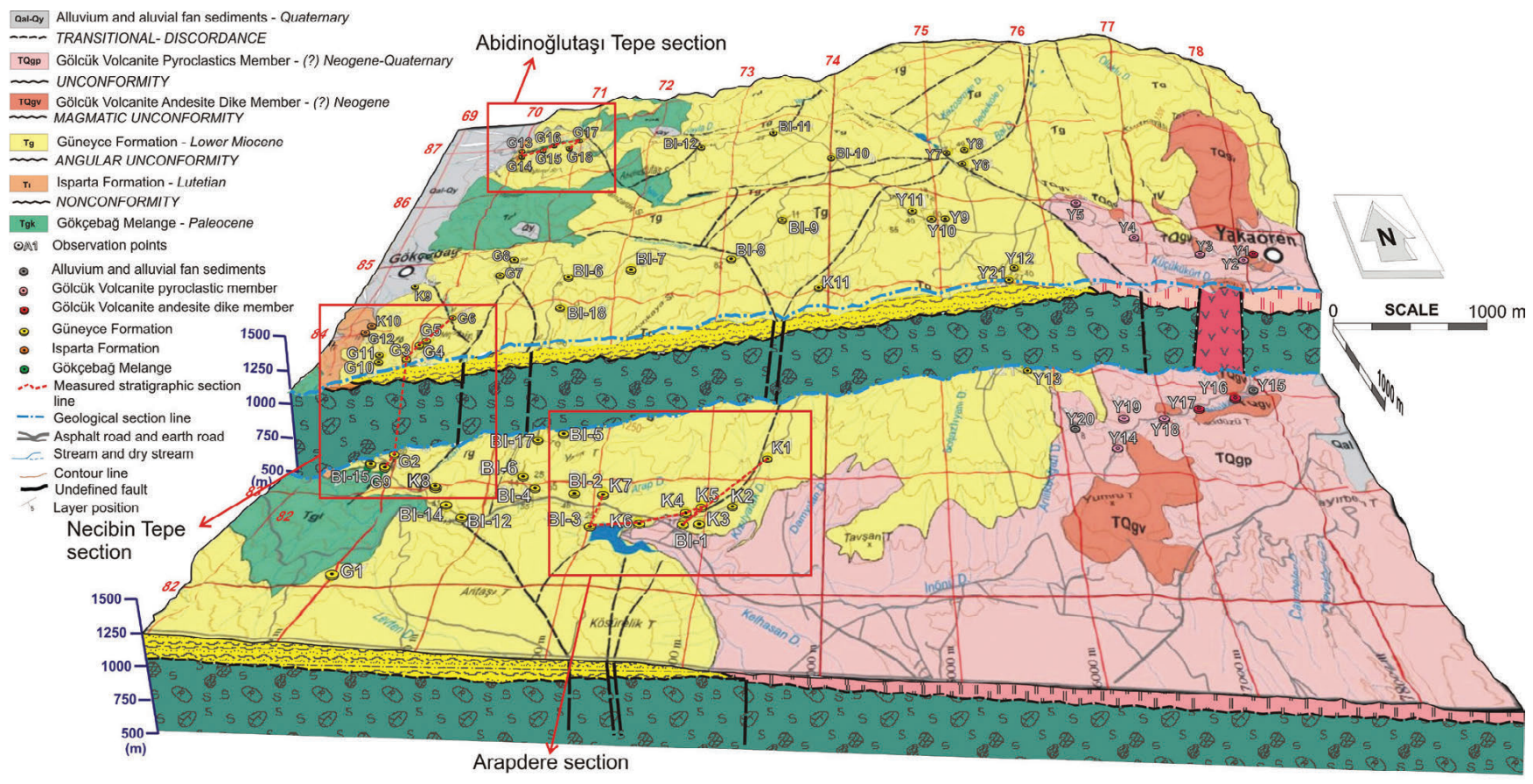

Figure 2. A new geologic 3D map was built based on nannofossil biostratigraphy (emended from YAVUZLAR \& SAGULAR, 2016).

of the Güneyce Formation begins with terrestrial deposits including gypsum and coal-bearing sandy-mudstones, and continues with rhythmic sandstone and mudstone/marl alternations including sand-dominated levels. Clastic rock packages seen are partially similar to the depositional facies 1-4a of GÖRMÜŞ et al. (2001).

\subsection{Stratigraphic sections}

The Necibin Tepe stratigraphic section (Figs. 3 A, 4) belongs to the first sedimentary levels of the Güneyce Formation overlying the ophiolitic melange. In the lower part of the succession (up to $44 \mathrm{~m}$ ), there are sandy mudstones with sandstone interbeds of sandy facies of the Güneyce Formation, followed by dolomitic limestone lenticular beds within the muddy marine sedimentation. In addition, these levels include lense-shaped gypsum and coal intercalations that could belong to very shallow olistostrome facies. Above sixty metres, there is a shallow marine sandstone and mudstone alternation in the upper part of the succession belonging to the rhythmic sandstone-mudstone facies of the Güneyce Formation. In the Necibin Tepe section, a transgression 

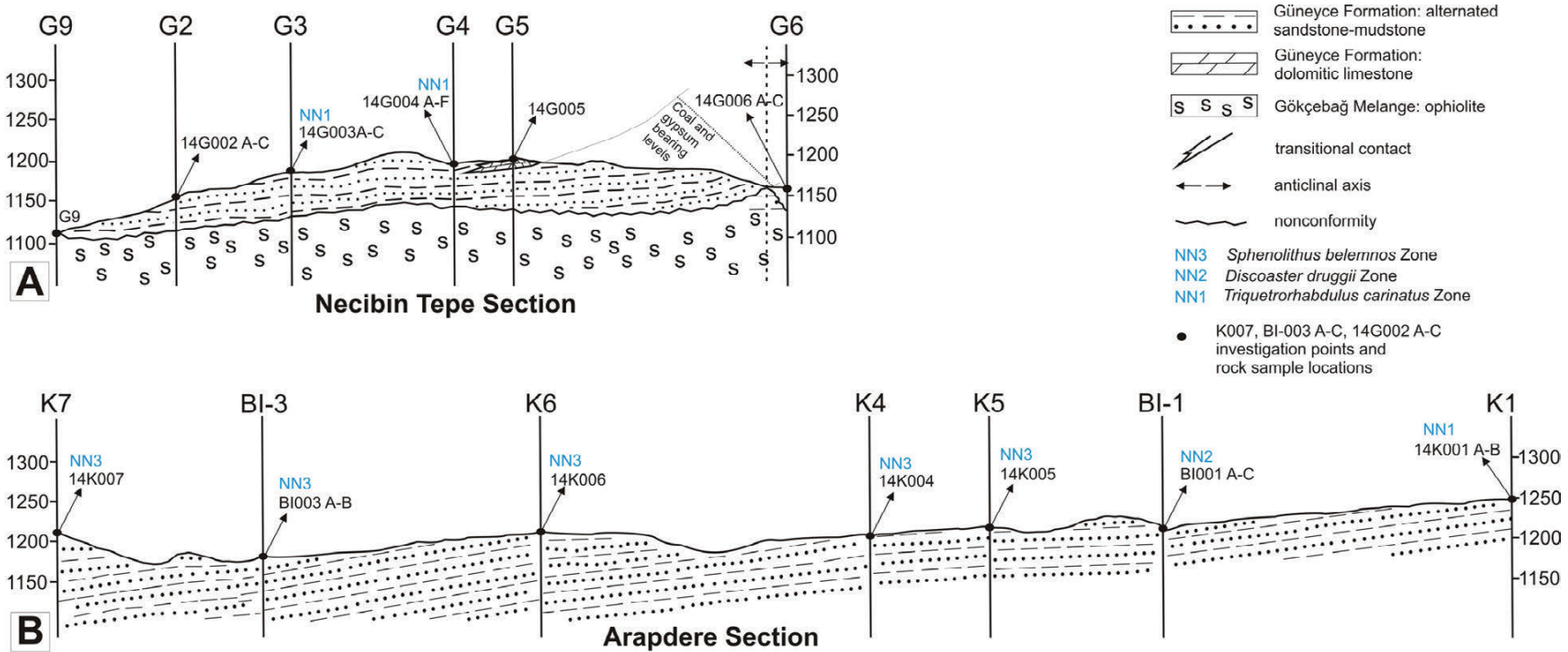
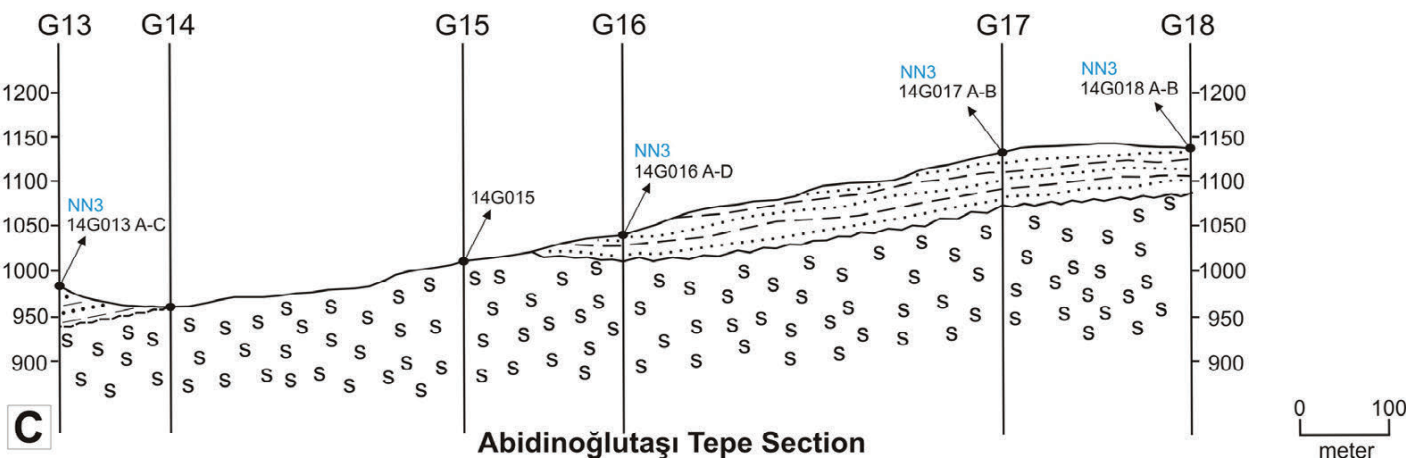

Figure 3. Measured stratigraphic sections in the Güneyce Formation: A. Necibin Tepe stratigraphic cross section, B. Arapdere stratigraphic cross section, C. Abidinoğlutaşı Tepe stratigraphic cross section (emended from YAVUZLAR \& SAGULAR, 2017).

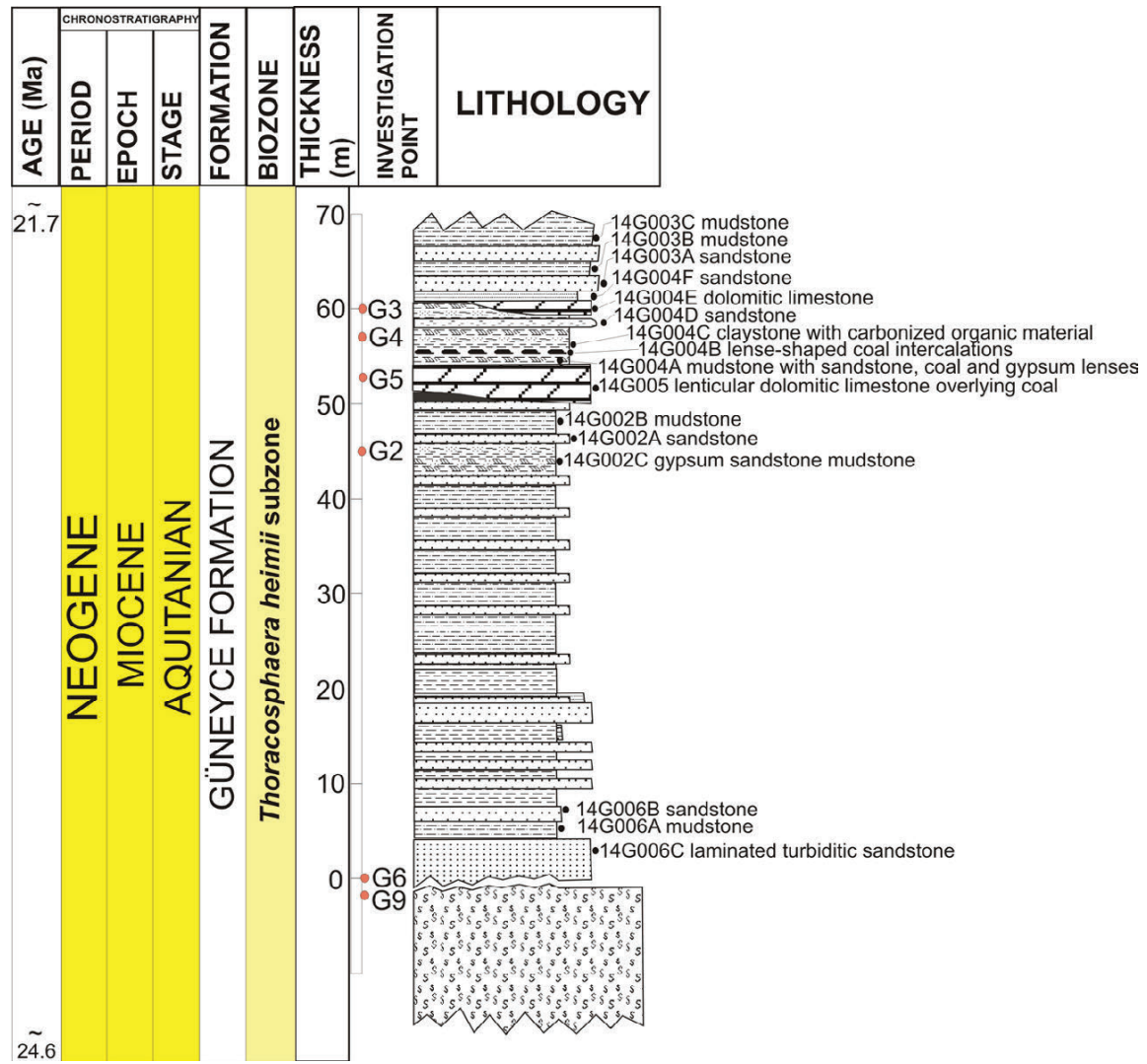

Figure 4. Lithostratigraphy of the Necibin Tepe section. 


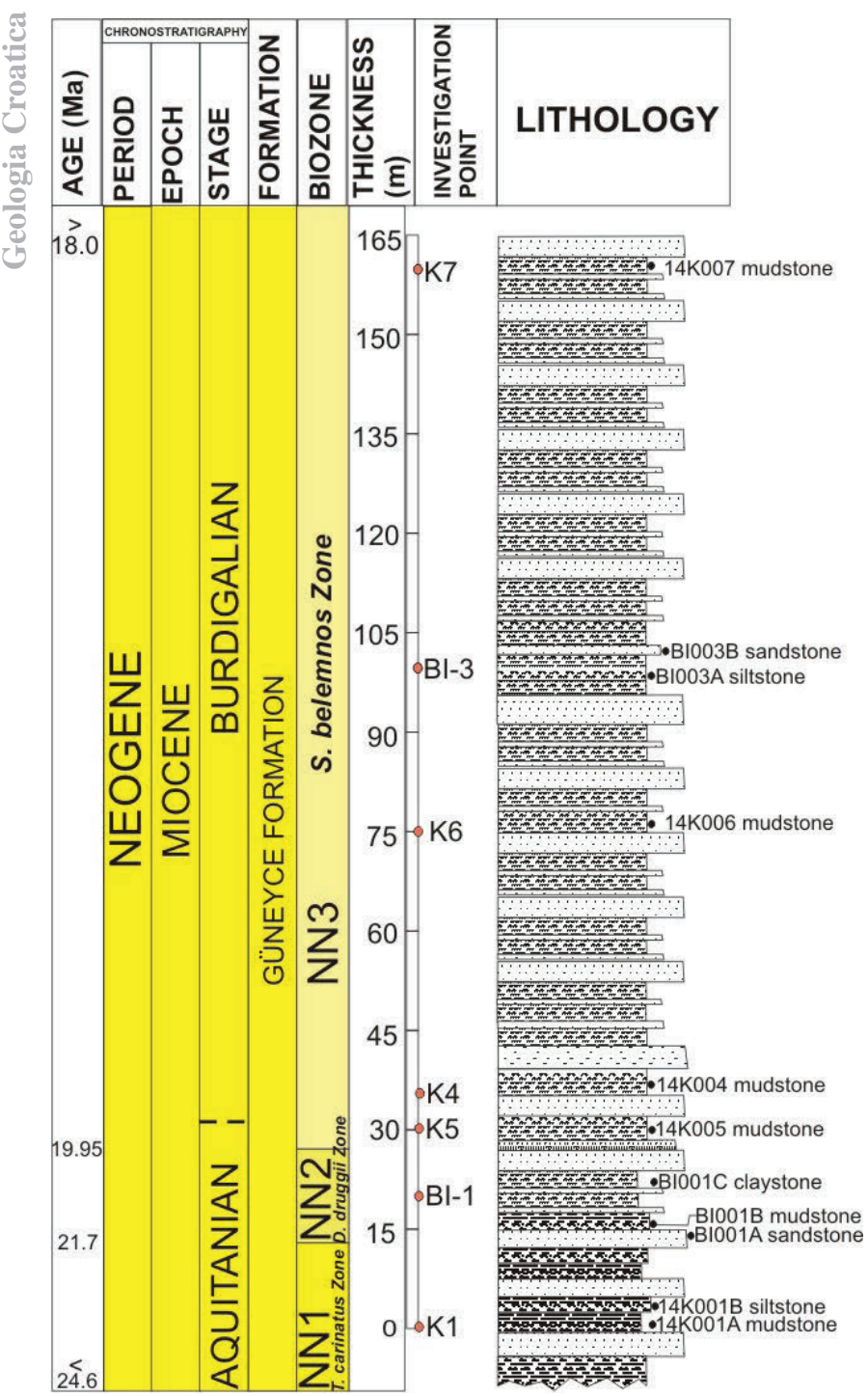

Figure 5. Lithostratigraphy of the Arapdere section.

resulted in deposition of shallow marine sediments on top of terrestrial sedimentary rocks and facies of the succession.

The Arapdere stratigraphic section (Figs. 3 B, 5) belongs to the middle levels of the Güneyce Formation following the sediments of Necibin Tepe section. Here, sediments and facies of the

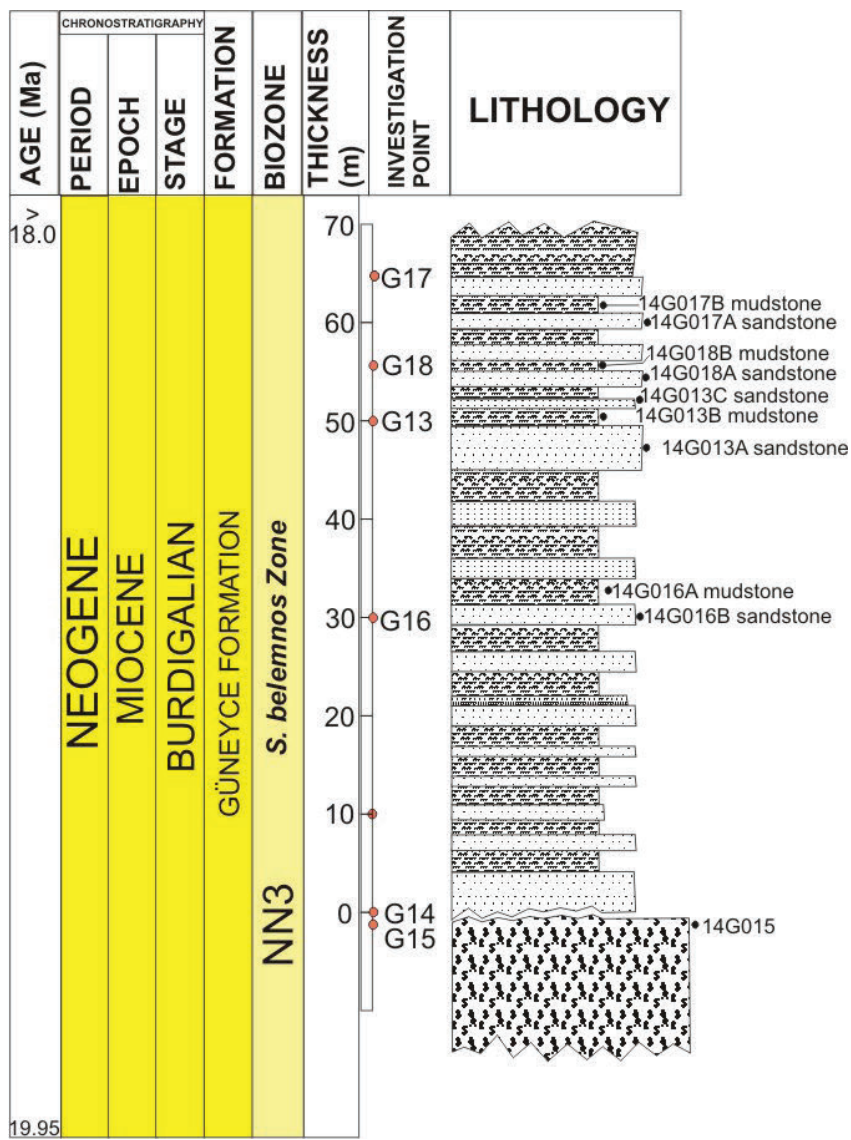

Figure 6. Lithostratigraphy of the Abidinoğlutaşı Tepe section.

succession exhibit the rhythmic alternations of mudstones and sandstones representing shallow marine sedimentation.

The Abidinoğlutaşı Tepe stratigraphic section (Figs. 3 C, 6) belongs to the rhythmic sandstone-mudstone facies of the Güneyce Formation, overlies the ophiolitic melange and coincides with the sediments of the Arapdere section. The sedimentary successions and facies of this section also include mudstone and sandstone rhythmic alternation representing shallow marine sedimentation.

\subsection{Investigation methods}

The standard nannofossil preparation method was used without applying any concentration or cleaning process and taxonomic

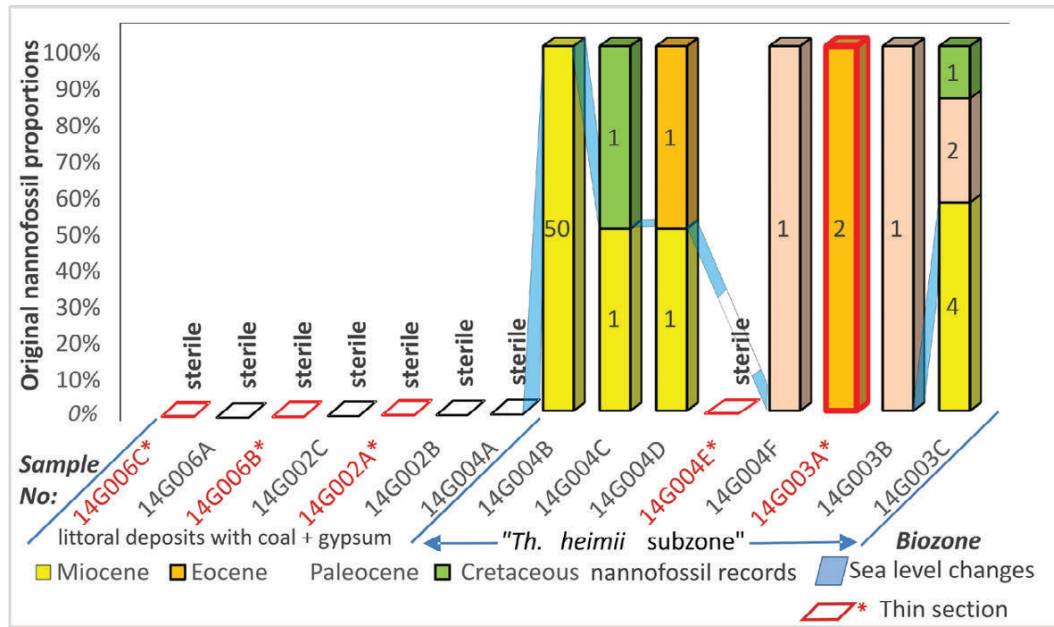

Figure 7. Distribution of original nannofossil percentages in the Necibin Tepe section (* indicates nannofossil data in thin section). 


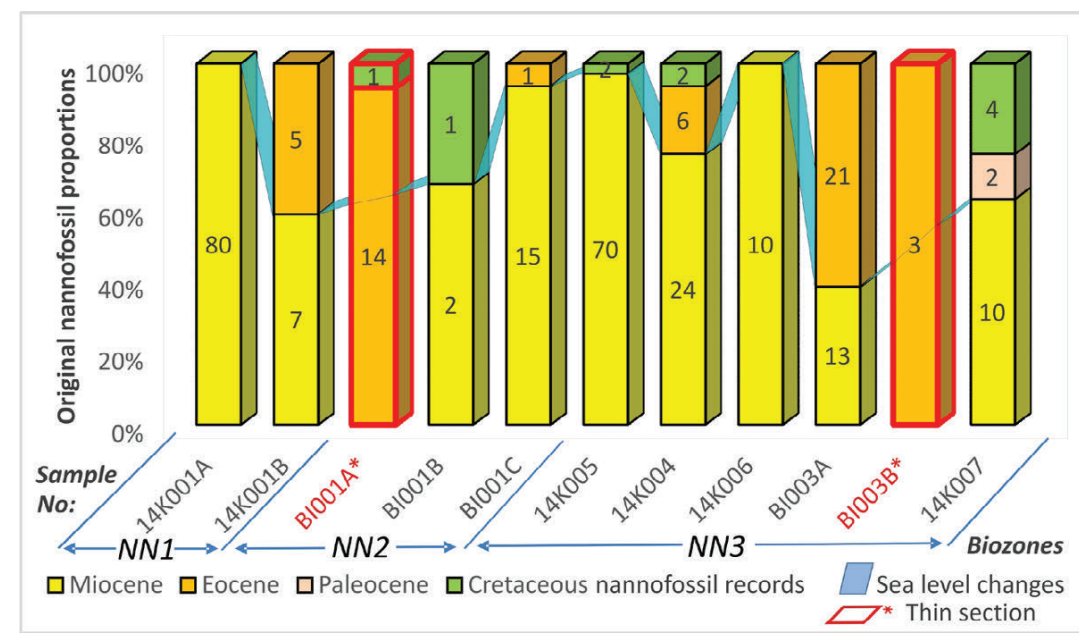

Figure 8. Distribution of original nannofossil percentages in the Arapdere section (*indicates nannofossil data in thin section).

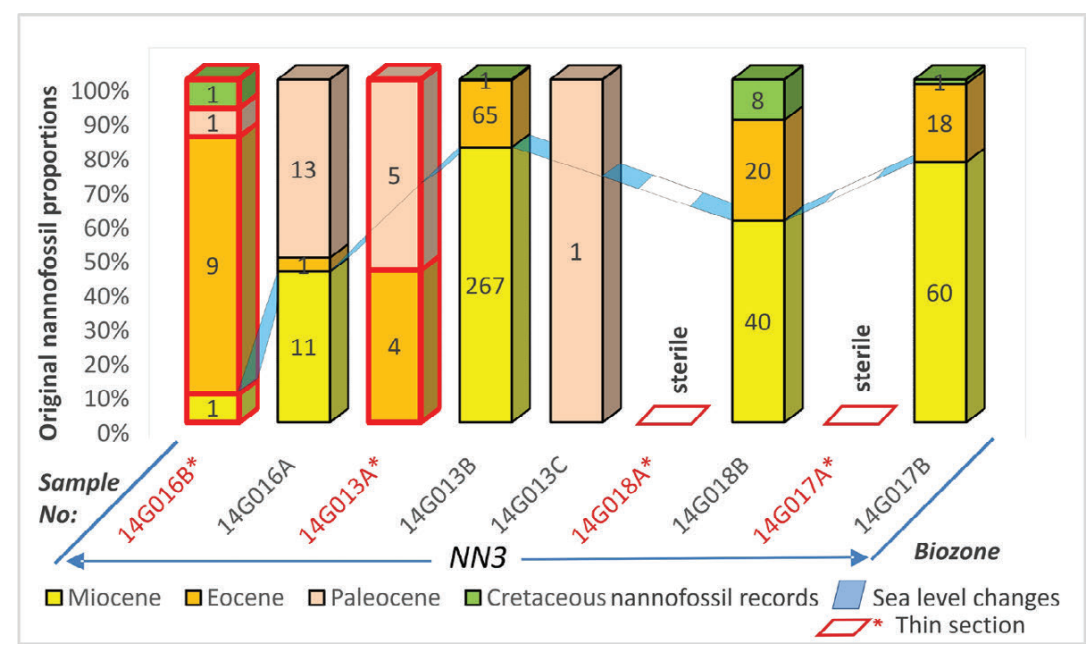

Figure 9. Distribution of original nannofossil percentages in the Abidinoğlutaşı Tepe section (* indicates nannofossil data in thin section).

concepts were followed PERCH-NIELSEN (1985a), BOWN \& YOUNG (1998). Analyses were carried out by polarized light microscopes at x2500 magnification, using a Nikon Optiphot-Pol and Leica DM2700 P, at the Department of Geology, Suleyman Demirel University. For each smear slide, nannofossil specimens were counted in 200 fields of view and the identified species were separated into two groups as autochthonous and reworked taxa.

In addition, thinned (20-25 microns) petrographic sections were prepared from coarse grained rock samples such as sandstone and limestone (SAGULAR, 2003a, 2003b). Nannofossil records within lithoclasts or within the matrix in thin-sections of a sandstone are considered to be mainly reworked sedimentary grains. The nannofossils within intraclasts or within the calcite cement of a calcarenite or limestone could be coeval with sedimentation (synsedimentary). Nannofossil records observed in lithoclasts are considered as reworked from extrabasin sources whereas those in intraclasts are considered as removed from elsewhere within the basin. Whereas, fossil data found in matrix or cement are considered either reworked or resedimented. Thus, the autochthonous or reworked nannofossil assemblages and their sedimentological properties were determined in both nannofossil smear-slides and thin-sections. The results of the laboratory determinations were correlated with field observations and previous studies.
MELINTE (2005), WADE \& BOWN (2006) used the nannofossil population as an indicator of sea level changes. SAGULAR (2003b) described another method based on reworked nannofossil data, where the reworked specimen proportions are used as an indicator of sea level changes in coastal environments. The method which SAGULAR (2003b) described is applied in this study.

\section{RESULTS}

\subsection{Nannofossil biostratigraphy}

Four nannofossil biozones according to MARTINI's (1971) zonation were identified (Fig. 10).

\subsubsection{Discoaster tani nodifer Zone (NP16)}

Definition: The last occurrence (LO) of Rhabdolithus gladius to the LO of Chiasmolithus solitus

Authors: HAY et al. (1967), emend. MARTINI (1970)

Age: Lutetian, Middle Eocene

Type locality: The NP16 Zone covers the Isparta Formation observed in only a few outcrops within the investigated area (south of Gökçebağ Village, west of the investigated area, Fig. 2).

Remarks on assemblage: The LO of Chiasmolithus solitus in the upper part of the zone and the first occurrence (FO) of Reticulofenestra umbilicus and LO Blackites inversus at the base 


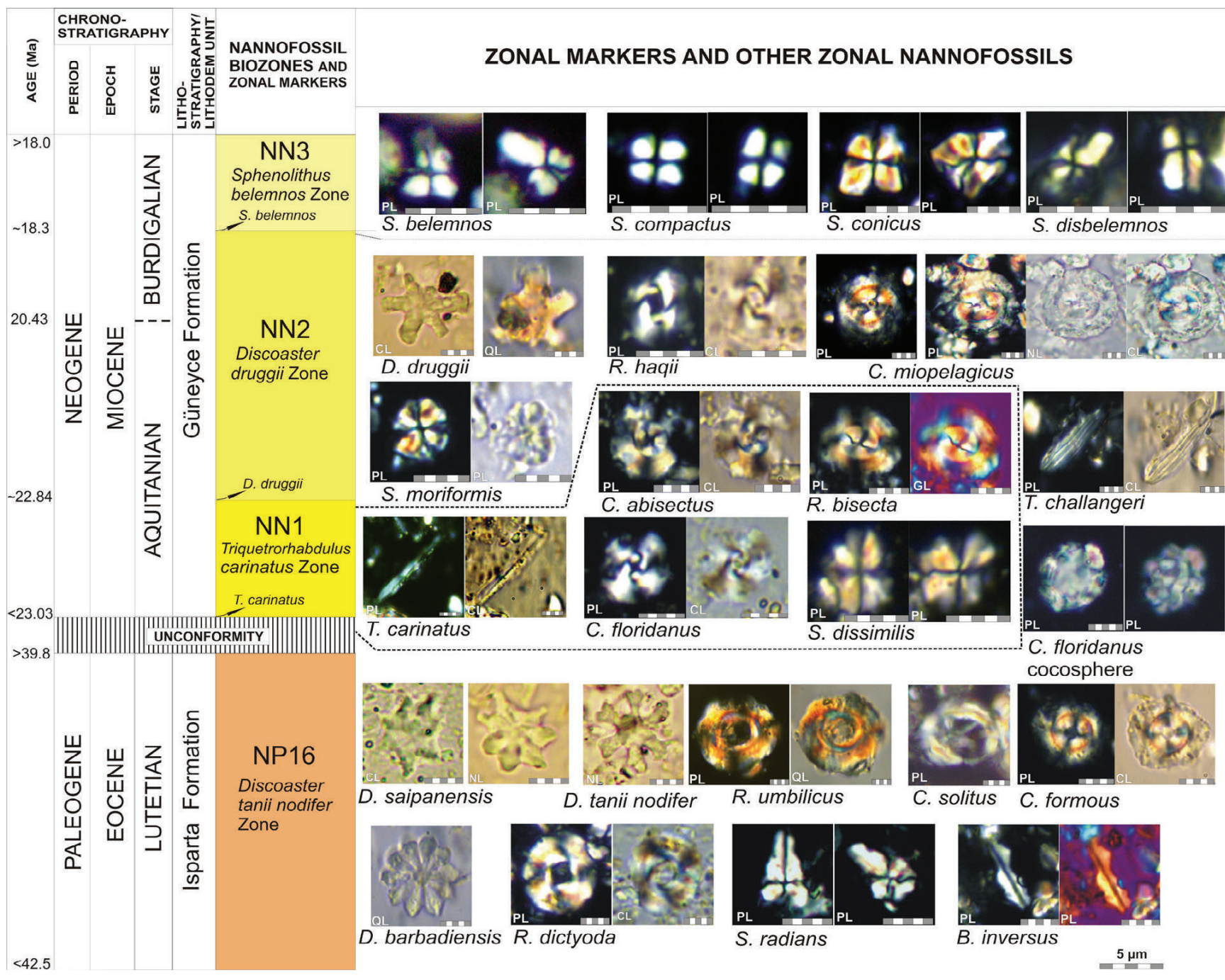

Figure 10. Biozones and marker nannofossils of the Isparta and the Güneyce formations.
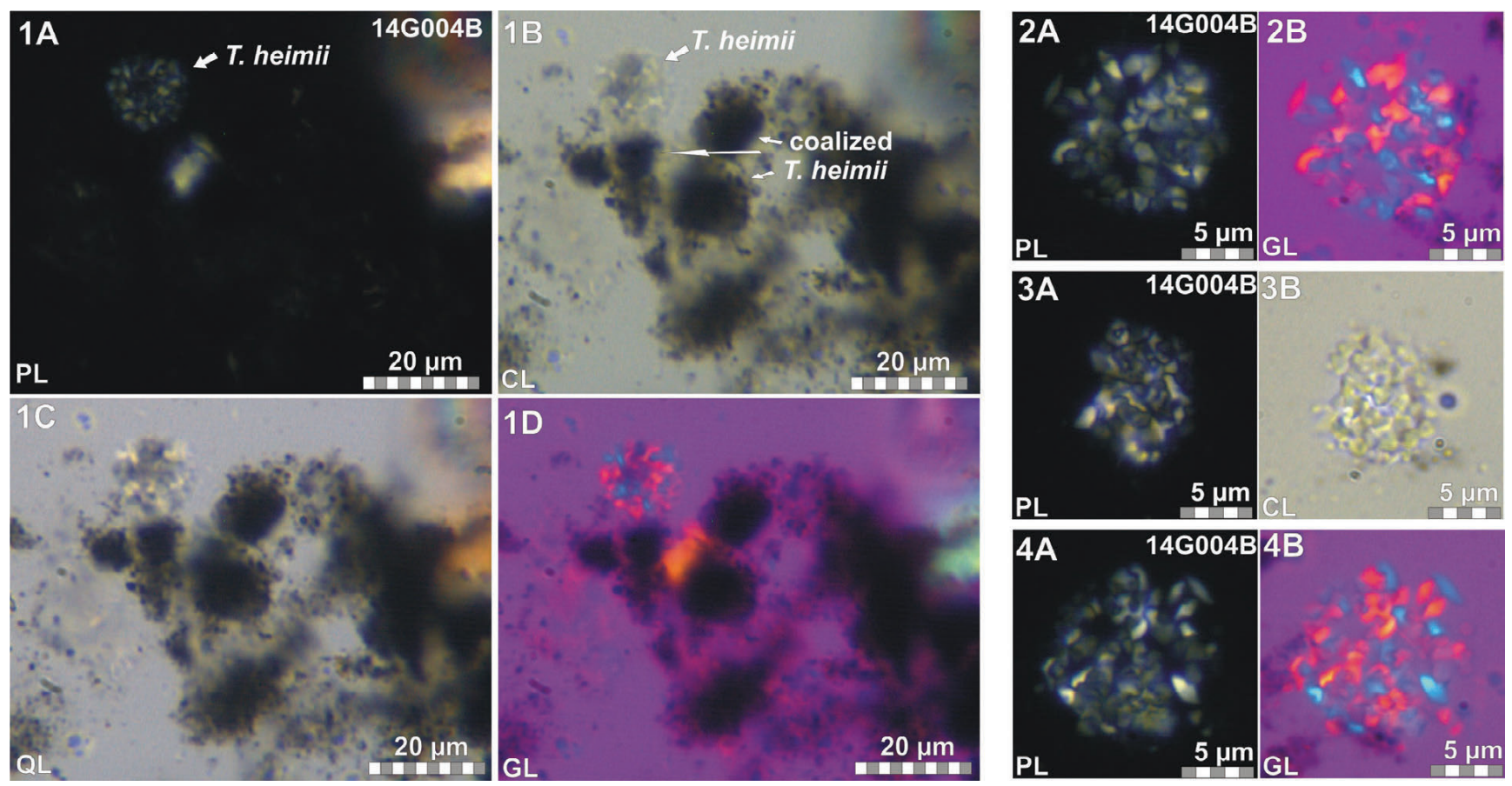

Figure 11. Smear slide images of dinoflagellate cysts in sample 14G004B:1A-D) T. heimii and coalized Thoracosphaera spp. (T. heimii ?); 2-4) T. heimii (PL: polarized light, CL: phase contrast, QL: with quartz wedge, GL: with gypsum wedge). 
Table 1. List of calcareous nannofossil species distribution, counts and percentages in the Necibin Tepe section $\left({ }^{*}\right.$ indicates thin section nannofossil data).

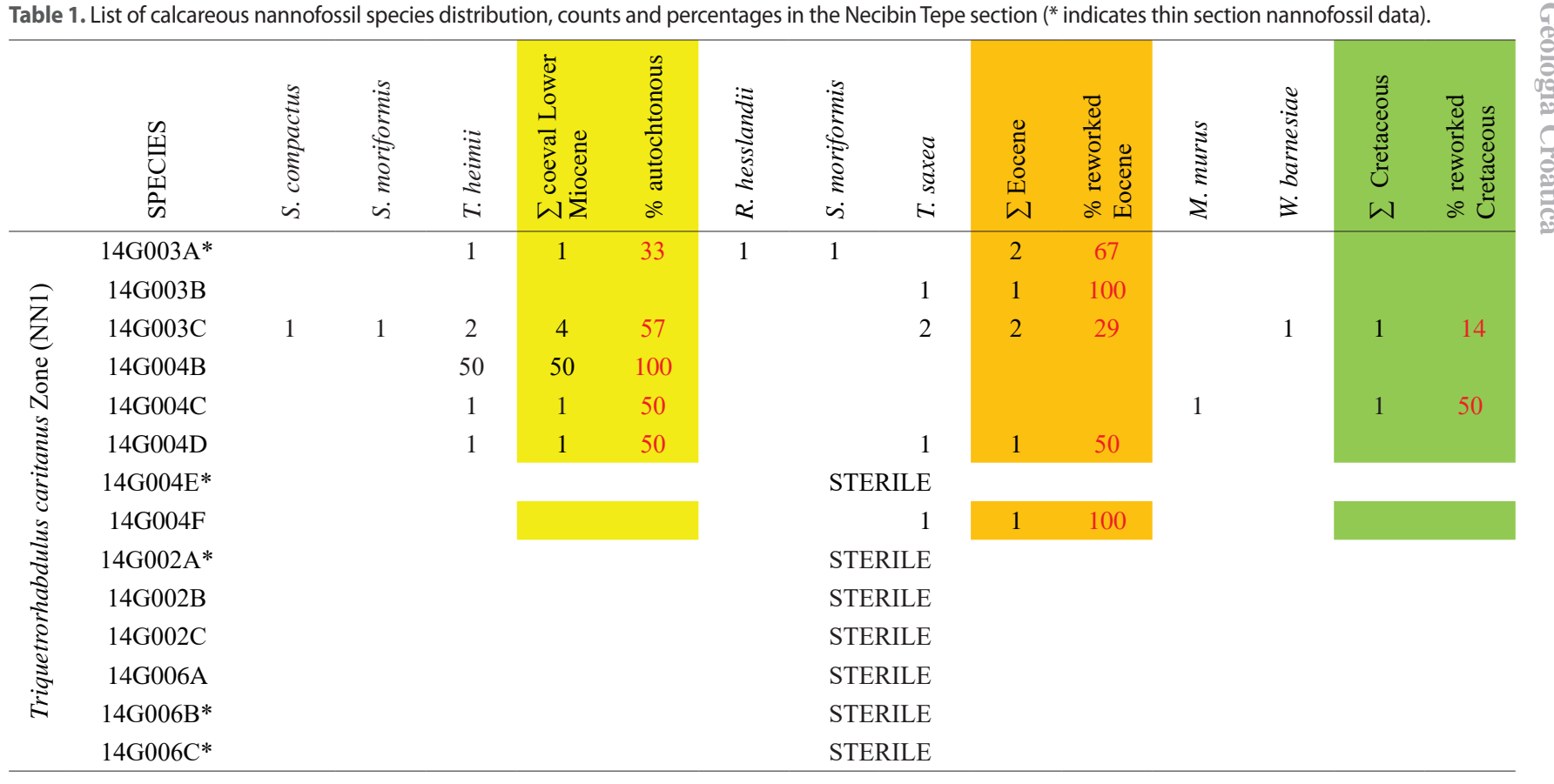

(BOWN \& NEWSAM 2017, PERCH-NIELSEN 1985) is noticed in the assemblage with $D$. saipanensis, $D$. tanii nodifer, $R$. dictyoda and $S$. radians and B. inversus.

\subsubsection{Triquetrorhabdulus carinatus Zone (NN1)}

Definition: LO of Helicosphaera recta and/or Sphenolithus ciperoensis to the FO of Discoaster druggii

Authors: BRAMLETTE \& WILCOXON (1967), emend. MARTINI \& WORSLEY (1970)

Age: Aquitanian, Early Miocene

Type locality: The base of the Arapdere section

Remarks on assemblages: The LO of Cyclicargolithus abisectus is observed in the assemblage with T. caritanus, $C$. flori- danus, Reticulofenestra bisecta, Sphenolithus dissimilis. In this zone, the presence of S. moriformis, S. compactus and T. heimii were observed in samples from the Necibin Tepe section. In the Arapdere section the following species were identified: C. miopelagicus, C. pelagicus, C. abisectus, C. floridanus, $R$. bisecta, $R$. gelida, $R$. producta, $S$. compactus, $S$. dissimilis, $S$. moriformis and $T$. carinatus.

\subsubsection{Discoaster druggii Zone (NN2)}

Definition: FO of Discoaster druggii to the LO of Triquetrorhabdulus carinatus.

Authors: MARTINI \& WORSLEY (1970)

Age: Aquitanian to Burdigalian, Early Miocene

Table 2. List of calcareous nannofossil species distribution, counts and percentages in the Arapdere section (* indicates thin section nannofossil data).

\begin{tabular}{|c|c|c|c|c|c|c|c|c|c|c|c|c|c|c|c|c|c|c|c|c|c|c|c|c|c|c|c|c|c|c|c|c|c|c|c|c|}
\hline 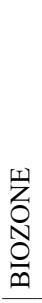 & 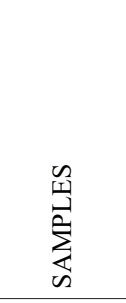 & 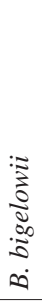 & 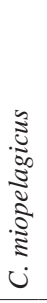 & 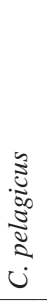 & 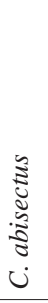 & 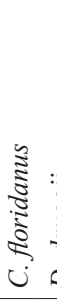 & 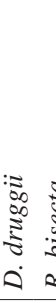 & 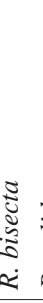 & 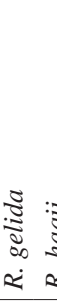 & 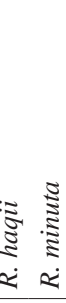 & $\begin{array}{c}0 \\
\frac{\pi}{0} \\
\frac{3}{0} \\
0 \\
\vdots \\
2 \\
2 \\
2\end{array}$ & 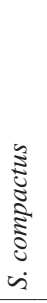 & 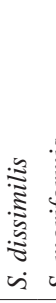 & 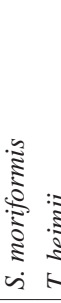 & 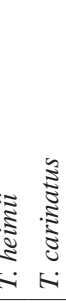 & 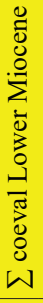 & $\begin{array}{c} \\
0 \\
0 \\
0 \\
0 \\
0 \\
0 \\
0 \\
0 \\
0 \\
0 \\
0\end{array}$ & 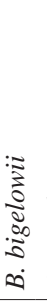 & 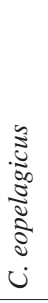 & 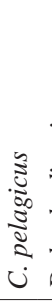 & 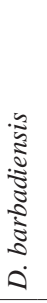 & 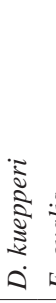 & : & 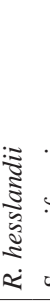 & 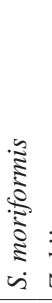 & 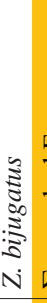 & 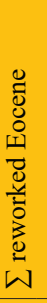 & 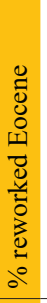 & 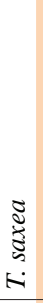 & 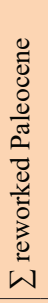 & 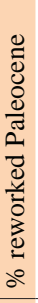 & \begin{tabular}{l} 
के \\
$\frac{0}{3}$ \\
\multirow{3}{*}{} \\
$\dot{z}$
\end{tabular} & 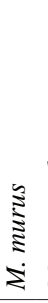 & 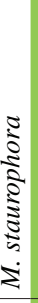 & 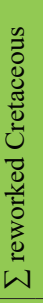 & 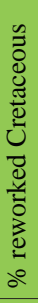 \\
\hline \multirow{6}{*}{ 学 } & 14K007 & & & & & 2 & & & & 6 & & & & 2 & & 10 & 62 & & & & & & & & & & & & 2 & 2 & 14 & 4 & & & 4 & 25 \\
\hline & BI003A & 1 & & 2 & & & & 4 & & 2 & & 4 & & & & 13 & 38 & 1 & 14 & 4 & & & 2 & & & & 21 & 62 & & & & & & & & \\
\hline & BI003B* & & & & & & & & & & & & & & & & & & & & 1 & & & & 2 & & 31 & 100 & & & & & & & & \\
\hline & 14K006 & & & 2 & & 2 & & 2 & & & 2 & & & $\begin{array}{ll}1 & 1\end{array}$ & 1 & 10 & 100 & & & & & & & & & & & & & & & & & & & \\
\hline & 14K004 & & 2 & 2 & & 6 & & 2 & & & & 4 & 2 & 6 & & 24 & 75 & & 2 & & 2 & & & & 2 & & 6 & 19 & & & & & 2 & & 2 & 6 \\
\hline & $14 \mathrm{~K} 005$ & & 12 & & 6 & 15 & & 8 & & 5 & & & 22 & 22 & & 70 & 97 & & & & & & & & & & & & & & & 2 & & & 2 & 3 \\
\hline \multirow{3}{*}{ 艺 } & BI001A* & & & & & & & & & & & & & & & & & 2 & & 1 & & 1 & & 1 & 9 & & 14 & 93 & & & & & & 1 & 1 & 7 \\
\hline & BI001B & & 1 & 1 & & & & & & & & & & & & 2 & 67 & & & & & & & & & & & & & & & & & 1 & 1 & 33 \\
\hline & $\mathrm{BI001C}$ & & & 1 & & 1 & 1 & 1 & & 1 & 3 & 1 & 1 & 3 & & 13 & 87 & & & & & & 1 & & & 1 & 2 & 13 & & & & & & & & \\
\hline \multirow{2}{*}{ 元 } & 14K001A & & 2 & 6 & 3 & 12 & & 18 & 2 & & 6 & 2 & 111 & 16 & 2 & 80 & 100 & & & & & & & & & & & & & & & & & & & \\
\hline & $14 \mathrm{~K} 001 \mathrm{~B}$ & & & & & 2 & & & & 2 & & 2 & & 1 & & 7 & 58 & & & & 2 & & 2 & & 1 & & 5 & 42 & & & & & & & & \\
\hline
\end{tabular}


Type locality: Arapdere section

Remarks on assemblages: Discoaster druggii, Reticulofenestra haqii, Coccolithus miopelagicus and Sphenolithus moriformis are present. Apart from the samples of the measured section, Triquetrorhabdulus challengeri were identified in the mudstone spot sample BI016D.

\subsubsection{Sphenolithus belemnos Zone (NN3)}

Definition: LO of Triquetrorhabdulus carinatus to LO of Sphenolithus belemnos

Authors: BRAMLETTE \& WILCOXON (1967)
Age: Burdigalian, Early Miocene

Type locality: Arapdere section and Abidinoğlutaşı Tepe section

Remarks on assemblages: Sphenolithus belemnos, S. disbelemnos, S. compactus and S. conicus are considered as marker species in this zone.

\subsection{Assemblage composition}

\subsubsection{Necibin Tepe section}

In this section fourteen samples were studied and half of them were sterile. The following species were identified: Sphenolithus
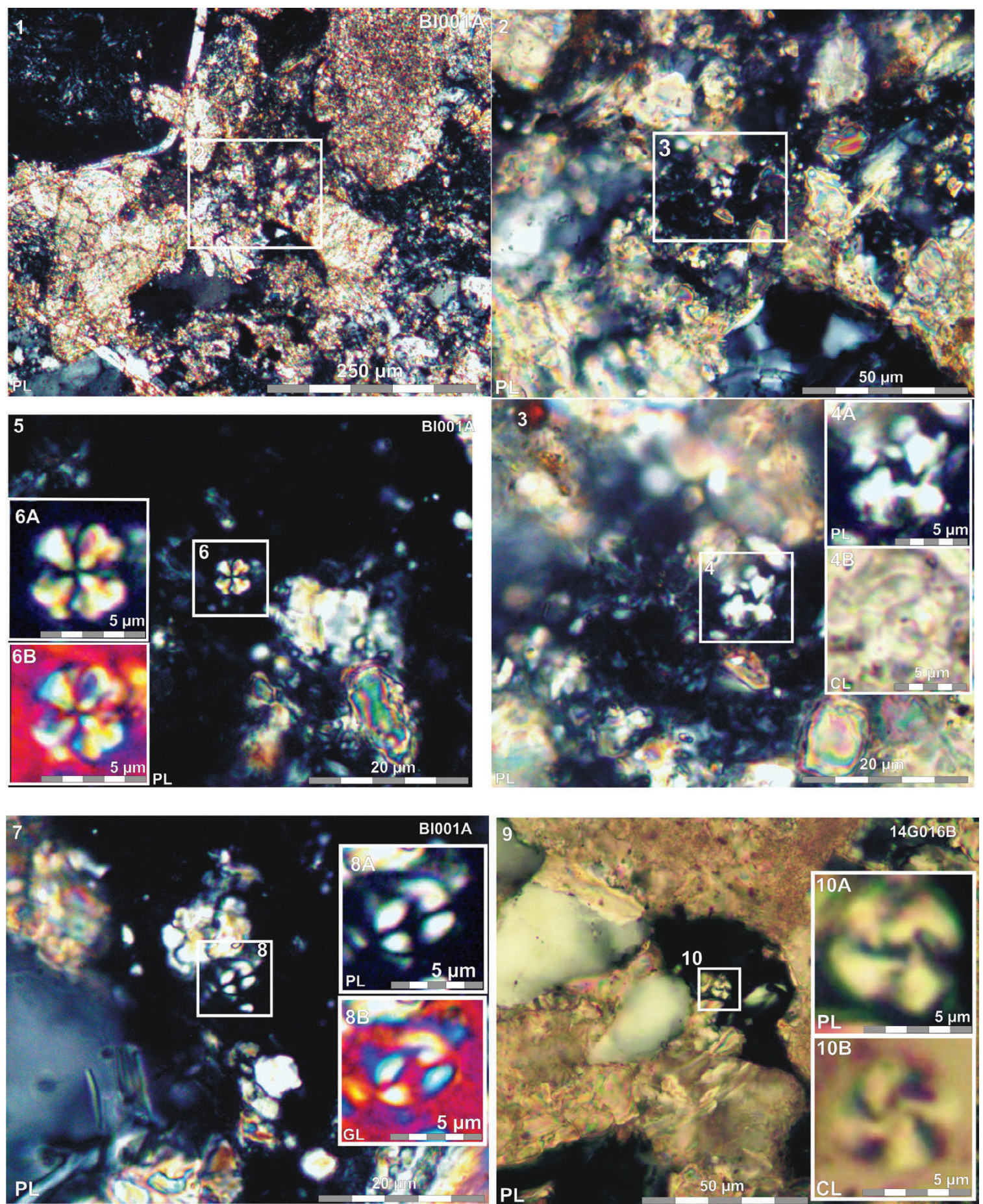

Figure 12. Thin section images with reworked nannofossil taxa in the matrix of sandstones 1-4) R. hesslandii, (Arapdere section, sample Bl001A) 5-6) S. moriformis, (Arapdere section, sample BI001A), 7-8) C. pelagicus (Arapdere section, sample BI001A), 9-10) C. floridanus (Abidinoğlutaşı Tepe section, sample 14G0013A) (PL: polarized light, CL: phase contrast, QL: with quartz wedge, GL: with gypsum wedge). 


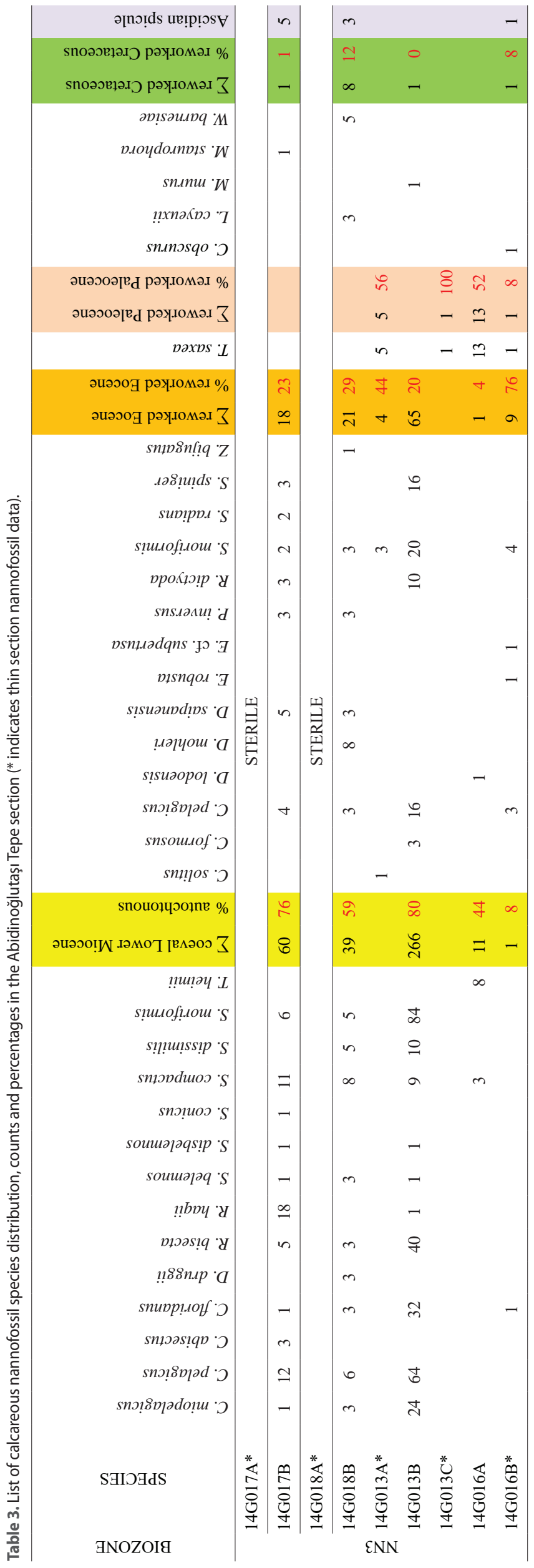

compactus, S. moriformis and Thoracosphaera heimii. Almost half of the assemblage contains reworked specimens from the Eocene: Reticulofenestra hesslandii, T. saxea and from the Cretaceous: Micula murus and Watznaueria barnesiae (Table 1).

Above $60 \mathrm{~m}$ in the section, deposits turn to the 4a rhythmic sandstone-mudstone facies of the Güneyce Formation defined in calcareous nannofossil NN1, NN2 and NN3 zones at the Arapdere section. Below $60 \mathrm{~m}$ in the section, sediments contain only very sparse Miocene Sphenolithus compactus, the first appearance of which is also observed in the NN1 Zone (PERCH-NIELSEN (1985) and AUBRY (1989)) in the autochthonous nannofossil assemblage with 33 to $67 \%$ reworked nannofossils from the Cretaceous and $33-100 \%$ from the Lutetian (Fig. 7). This section is very close to the Arapdere section (Fig. 2) and it is positioned at the base of the Arapdere section.

\subsubsection{Arapdere section}

From a total of eleven samples, two were thin-sections and contain reworked nannofossil taxa. These samples contain: Braarudosphaera bigelowii, Coccolithus miopelagicus, C. pelagicus, Cyclicargolithus abisectus, C. floridanus, Discoaster druggii, Reticulofenestra bisecta, $R$. gelida, $R$. haqii, $R$. minuta, $R$. producta, S. compactus, S. dissimilis, S. moriformis, T. heimii and T. carinatus. The reworked assemblage from the Eocene contains: B. bigelowii, C. eopelagicus, C. pelagicus, Discoaster barbadiensis, D. kuepperi, E. ovalis, R. hesslandii, S. moriformis, Z. bijugatus. T. saxea is determined as reworked from the Paleocene. The reworked Cretaceous nannofossils are Micula sp., M. murus and M. staurophora (Table 2).

In the samples of the Arapdere section, the NN1 zone contains $28 \%$ autochthonous and $72 \%$ reworked nannofossils. The NN2 zone contains from 50 to $60 \%$ autochthonous and 40 to $50 \%$ reworked forms. The NN3 zone includes 58 to $98 \%$ autochthonous forms and between 2 and 42\% reworked nannofossil taxa (Fig. 8).

\subsubsection{Abidinoğlutaşı Tepe section}

Of nine samples studied, five were thin sections and two were sterile smear slides. The autochthonous species are C. miopelagicus, C. pelagicus, C. floridanus, D. druggii, $R$. bisecta, $R$. haqii, Sphenolithus belemnos, S. disbelemnos, S. compactus, S. conicus, S. dissimilis, S. moriformis, T.heimii. The reworked species are as follows from the Eocene: Chiasmolithus solitus, Coccolithus formosus, C. pelagicus, Discoaster lodoensis, D. mohleri, D. saipanensis, Ericsonia robusta, E. subpertusa, Pyrocyclus inversus, Reticulofenestra dictyoda, S. moriformis, S. radians, S. spiniger and Z. bijugatus. Paleocene taxa include: T. saxea and from the Cretaceous, the following were determined: Calculites obscurus, Lucianorhabdus cayeuxii, M. murus, M. staurophora and Watznaueria barnesiae. In samples 14G017B, 14G018B and 14G016B ascidian spicules were observed (Table 3).

The autochthonous species belonging to the NN3 zone display percentages from 50 to $73 \%$ and reworked species comprise 27 to $50 \%$ of the assemblage (Fig. 9).

\section{DISCUSSION}

\subsection{Biostratigraphy and palaeoecology}

Previous studies in this region were undertaken by GÖRMÜŞ et al. (2001) who first identified the NN1 and NN2 zones. The NN1 Zone was defined by the presence of: C.floridanus, C. abisectus, C. pelagicus, Discoaster deflandrei, D. bisectus, Helicosphaera obliqua, S. conicus, S. compactus, S. dissimilis and Z. bijugatus. The NN2 Zone was defined by the presence of Discoaster drug- 
gii, D. deflandrei, C. floridanus, C. abisectus, Calcidiscus sp, and $S$. dissimilis. These zones are very diverse and were determined in relatively deeper marine environments than presented here.

In this region, the NN3 zone was first described by HEPDENIZ \& SAGULAR (2009), defined by the presence of Triquetrorhabdulus carinatus, Discoaster cf. druggii, Sphenolithus belemnos, Dictyococcites perplexus, Pyrocyclus cf. orangensis, Reticulofenestra haqii, Sphenolithus compactus, Sphenolithus conicus, Coccolithus miopelagicus.

A general distinction of autochthonous and reworked nannofossil taxa allows the definition of depositional and paleoenvironmental characteristics and leads to more reliable sedimentary and stratigraphic interpretations, especially for a fluctuating and unfavourable coastal environment (SAGULAR, 2003a, b). In this type of environment, marine deposits, such as the Güneyce Formation, generally contain very low amounts of autochthonous nannofossil assemblages. Reworked nannofossil assemblages are predominant in the sediments of the Güneyce Formation (Tables 1, 2 and 3). While autochthonous nannofossils display percentages between 33 and $100 \%$, the reworked taxa account for between 6 and $100 \%$ of the assemblage composition. Based on the generally very high percentages of reworked taxa in the assemblages the Güneyce Formation can be interpreted as representing a very shallow marine environment (Figs. 7, 8 and 9).

The calcareous nannofossil assemblages of the Güneyce Formation, are dominated by the Sphenolithus genus, as being more common in lower latitudes, preferring warm and shallow waters than open ocean (PERCH-NIELSEN 1985b). According to WEI
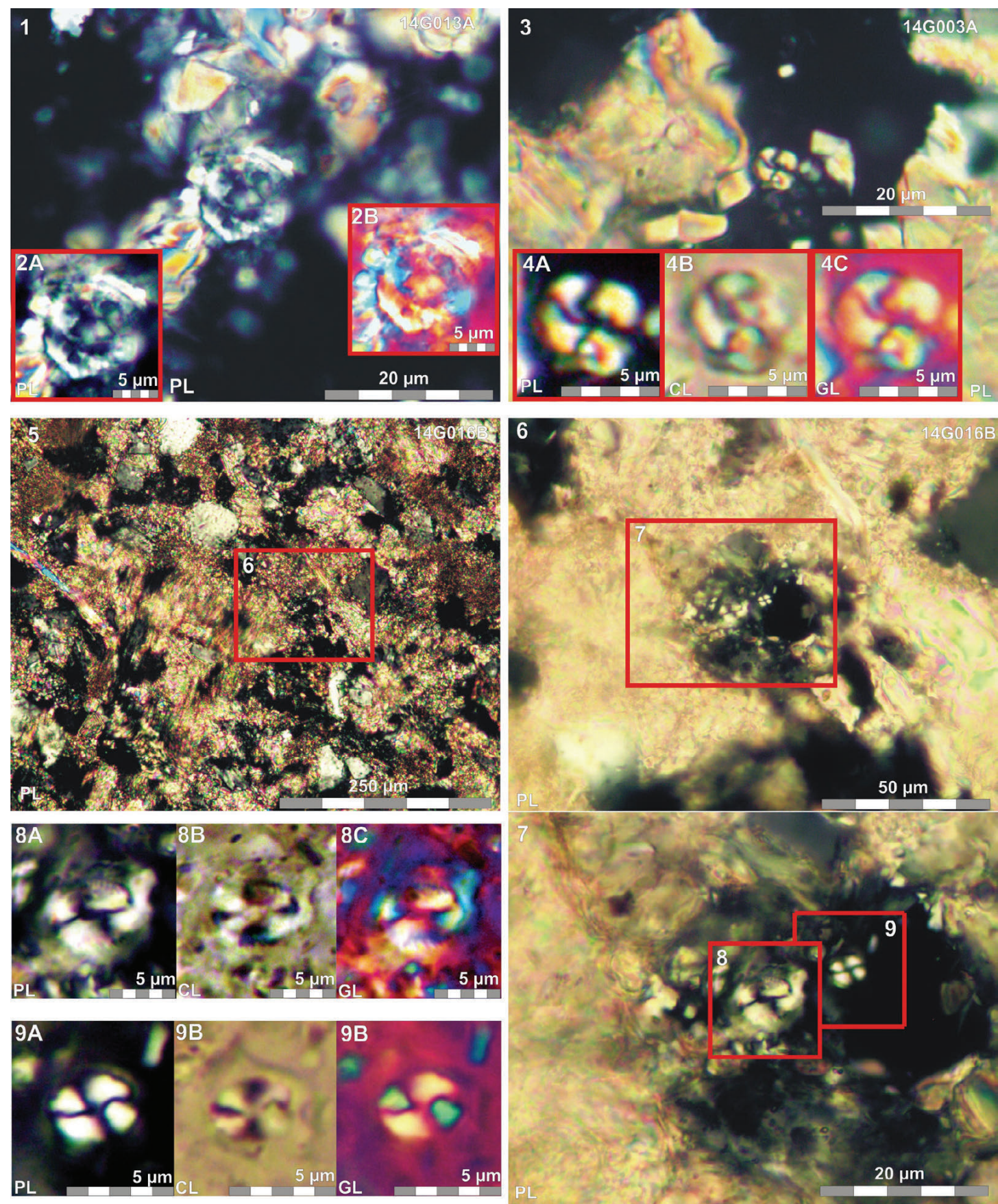

Figure 13. Thin section images of sandstones with reworked nannofossil taxa 1-2) C. solitus in lithoclast (Abidinoğlutaşı Tepe section, sample 14G0013A), 3-4) $R$. hesslandii in matrix (Necibin Tepe section, sample 14G003A); 5-8) C. pelagicus in matrix, and 5-7 \& 9) C. pelagicus in matrix (Abidinoğlutaşı Tepe section, sample 14G013A) (PL: polarized light, CL: phase contrast, QL: with quartz wedge, GL: with gypsum wedge). 

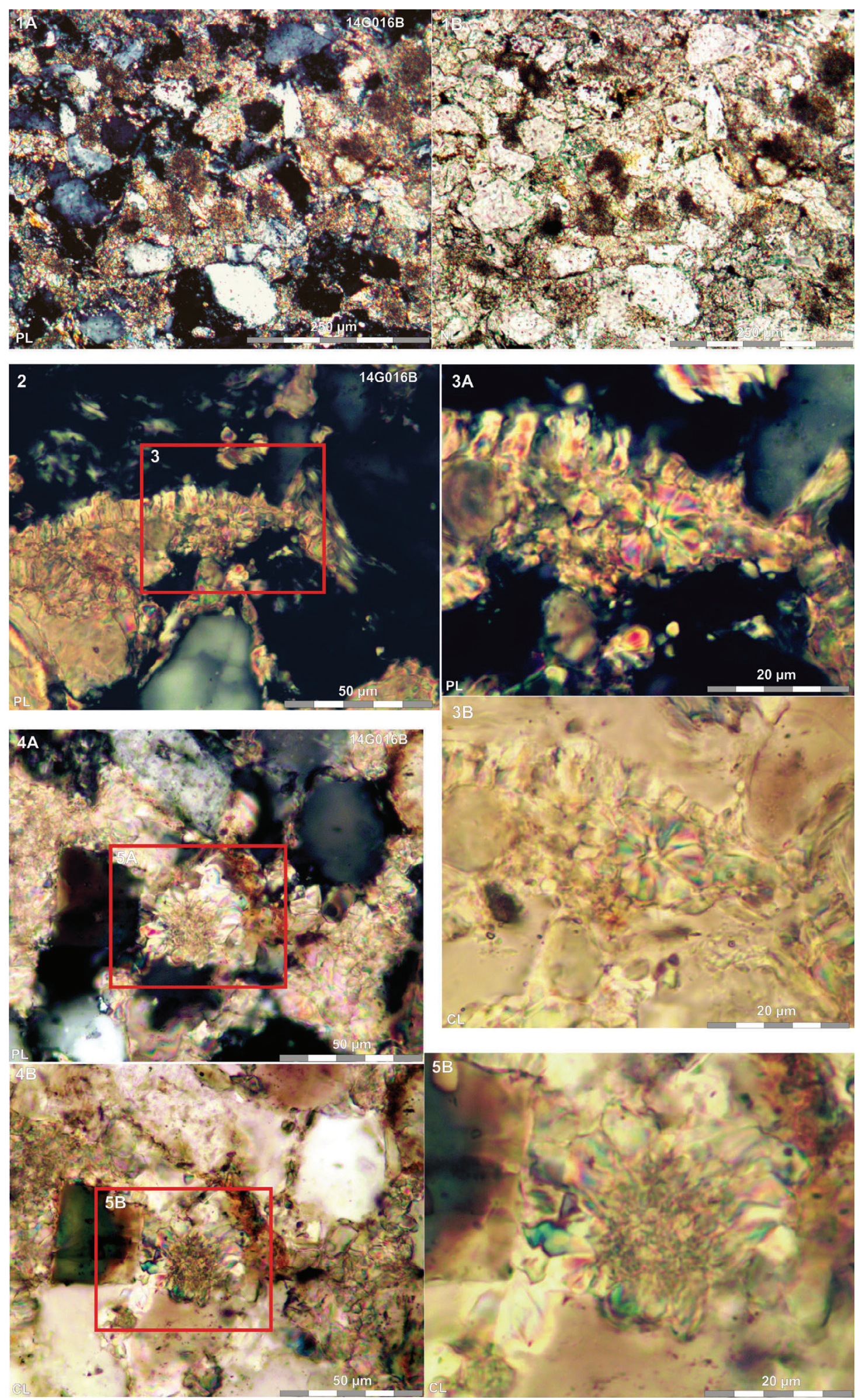

Figure 14. Thin section images of sedimentary structures in sandstone sample 14G0016B of the Abidinoğlutaşı Tepe section 1) General view of the sandstone, 2-3) Isopachous rim cement and ascidian spicule enclosed in intergranular sparry calcite cement of an intertidal sandstone, 4-6) Neomorphic fibrous fine crystalline spherulite FLÜGEL (1982). 
\& WISE (1990) sphenolith diversity is higher in equatorial sites, being less diverse in the mid-latitude areas. Only S. moriformis existed in the high-latitude sites. Within the whole asemblage, 150 individuals were counted and S. moriformis is presented here as the most abundant species. Based on the work of the aforementioned authors Sphenolithus spp. abundance and diversity indicate a shallow marine environment of the mid-latitudes.

\subsection{Necibin Tepe section}

The clastic levels in approximately the first $44 \mathrm{~m}$ of the section have no nannofossil data due to a prevailing terrestrial or shoreline environment (Figure 4, Table 1). From 44 m - 60 m, the presence of gypsum and microalgal (derived from dinoflagellate cysts) sapropelic coal lenses can be observed in the muddy levels of the succession. Due to the presence of such coal (Fig. 11) and gypsum lenses in the samples of the Necibin Tepe section, it is considered that the Early Miocene sedimentation was started in terrestrial and continued to occur in a littoral environment (Fig. 7). Besides, nannofossil data indicate the NN1 biozone, this section includes the beginning of the Early Miocene sedimentation of the Güneyce Formation.

\subsection{Arapdere section}

Depending on the original distribution of nannofossil assemblages within the Miocene to Cretaceous (Table 2), the Arapdere section represents transgressive shallow marine sediment levels in the Güneyce Formation. They include beach sediments or shoreline sandstones representing shallow marine environments such as littoral, tidal or the offshore-transitional zone or clastic shelf and contain mudstones with low coeval nannofossil contents. The distribution of autochthonous and reworked nannofossils in rock samples indicate sea level fluctuations in the Early Miocene shoreline transgression (Figs. 8 and 12).

\subsection{Abidinoğlutaşı Tepe section}

According to the nannofosil records of the Abidinoğlutaş1 Tepe section, autochthonous nannofossil species decrease from the bottom levels and then become dominant again in the upper parts of the section (Fig. 9, Table 3). The interpretation of this section is that the sediments of these levels represent shallow marine depositional environments. Additionally, the presence of ascidian spicules in the samples 14G017B, 14G018B and 14G016B (Table 3) can be considered as an indicator of a shallow environment (VAN NAME, 1945). From the bottom to the top of the section, the transgressive character and sea level fluctuations continue throughout. The proportions of autochthonous and reworked nannofossil assemblages in the samples of the Abidinoğlutaşı Tepe section indicate a generally transgressive trend with unstable sea level change observed in a very shallow coastal environment during the Burdigalian after the beginning of the Miocene (Figs. 9, 13 and 14).

Based on the new results, in addition to previous studies in the southern part of Isparta (GÖRMÜŞ et al., 2001; HEPDENIZ \& SAGULAR, 2009), the marine carbonate and clastics of the Isparta Formation were deposited during the Lutetian and the shallow marine shelf clastics of the Güneyce Formation were deposited during the Lower Miocene.

\section{CONCLUSIONS}

The following nannofossil biozones are represented in this study: the NP16 - Discoaster tanii nodifer Zone, which was defined in the Isparta Formation and three zones in the Lower Miocene: the NN1 - Triquetrorhabdulus carinatus Zone, NN2 - Discoaster druggii Zone and NN3 - Sphenolithus belemnos Zone in the Güneyce Formation. Based on the high amount of reworked nannofossil species the Güneyce Formation was probably deposited in a shallow marine environment.

The map of the study area was refined and two marine clastic sedimentary units were revised and described (the Isparta and Güneyce Formations). An Ophiolitic melange (Gökçebağ melange) was illustrated in regional maps in former studies as having been thrust over all the sedimentary sequence, in this study the map is modified according to the presented results. Marine clastic sediments unconformably overlie the ophiolitic melange. In addition, the 3D geologic map of the study area is revised and presented here.

\section{ACKNOWLEDGMENT}

The data of this study supported by the BAP 3913-YL1-14 project of Süleyman Demirel University. The authors are thankful to Madalina-Elena KALLANXHI (Babeș-Bolyai University, Romania) for suggestions and comments on the manuscript and would also like to thank two anonymous reviewers for their comments and helpful suggestions.

\section{REFERENCES}

AKBULUT, A. (1980): Eğirdir Gölü güneyinde Çandır (Sütçüler-Isparta) yöresindeki Batı Torosların jeolojisi [The geology of the Western Taurids in the area of Çatıdır (Sütçüler, İsparta), south the Ĕgridir Lake - in Turkish, with an English Abstract].Bulletin of Geological Society of Turkey, 23/1, 1-9.

AUBRY, M.P. (1989): Handbook of Cenozoic calcareous nannofossils, Book 3.- New York: Micropaleontology Press, $279 \mathrm{p}$

BARRIER, E. \& VRIELYNCK, B. (2008): Map 12. Early Burdigalian (20.4-17.4 Ma), in Palaeotectonic maps of the Middle East: tectono-sedimentary-palinspastic maps from Late Norian to Pliocene, Commission for the Geological Map of the World.

BOWN, P.R. \& NEWSAM, C. (2017). Calcareous nannofossils from the Eocene North Atlantic Ocean (IODP Expedition 342 Sites U1403-1411).- Journal of Nannoplankton Research, 37/1, 25-60.

BOWN, P.R. \& YOUNG, J.R. (1998): Techniques. In: Bown P.R. (Ed.): Calcareous nannofossil biostratigraphy.- Kluwer Academic Publications, Dordrecht, 16-28. doi: 10.1007/978-94-011-4902-0_2

BRAMLETTE, M.N. \& WILCOXON, J.A. (1967): Middle Tertiary calcareous nannoplankton of Cipero Section, Trinidad, W. I. Tulane Stud. Geol., 5, 93-131.

FLÜGEL, E. (1982): Microfacies Analysis of Limestones.- Translated by K. Chresresen, Springer-Verlag, Berlin, 633 p. doi: 10.1007/978-3-642-68423-4

GÖRMÜŞ, M. \& ÖZKUL, M. (1995): Gönen-Atabey (Isparta) ve Ağlasun (Burdur) Arasindaki Bölgenin Stratigrafisi [Stratigraphy of Gönen-Atabey (Isparta) and Ağlasun (Burdur)- in Turkish, with an English Abstract].- Suleyman Demirel University Journal of Science Institute, 1, 43-64, Isparta.

GÖRMÜŞ, M., SAGULAR, E.K. \& ÇOBAN, H. (2001): The Miocene sequence characteristics, its contact relation to the older rocks and lamprophyric dikes in the Dereboğazı area (southern Isparta, Turkey).- Proceedings of the 4th International Symposium on Eastern Mediterranean Geology, Isparta, 69-90.

GÖRMÜŞ, M., SAGULAR, E.K., BOZCU, A., UYSAL, K. \& POISSON, A. (2004): Why is reworking important? An example from the Cretaceous and Tertiary sediments around Isparta (SW Turkey).- Proceedings of the 4th International Congress 'Environmental Micropaleontology, Microbiology and Meiobenthology', Isparta, 84-87.

GUTNIC, M., MONOD, O., POISSON, A. \& DUMONT, J.F. (1979): Geologie des Taurides occidentales (Turquie).- Memories Société géologique de France, 137, 1-112.

HEPDENIZ, K. \& SAGULAR, E.K. (2009): Direkli ve Darıdere Köyleri (Isparta güneyi) yöresindeki Tersiyer yaşlı denizel kırıntılılarının nannofosil verilerinin kökensel ayırımına dayanan stratigrafik çözümlemesi [Stratigraphical analysis based upon generic discrimination of the nannofossil data of the Tertiary-aged marine clastics around the district of Direkli and Dartdere villages (South of Isparta) - in Turkish, with an English Abstract]. - Suleyman Demirel University Journal of Science Institute, 13/3, 245-264

KARAMAN, M.E. (1990): Isparta güneyinin temel jeolojik özellikleri [Basic geological characteristics of southern İsparta - in Turkish, with an English Abstract].- Geological Bulletin of Turkey, 33, 57-67.

KARAMAN, M.E. (1994): Isparta-Burdur arasının jeolojisi ve tektonik özellikleri [Geology and tectonic features between Isparta and Burdur area (SW Turkey) - in Turkish, with an English Abstract].- Geological Bulletin of Turkey, 37/2, 119-134.

MARTINI, E. (1971): Standard Tertiary and Quaternary calcareous nannoplankton zonations.- In: FARINACCI, A. (ed.): Proceedings $2^{\text {nd }}$ International Conference on Planktonic Microfossils, Roma 1970. Rome Ed. Tecnoscienza, 2, 739-785. 
MARTINI, E. \& WORSLEY, T. (1970): Standard Neogene calcareous nannoplankton zonation.- Nature, 225, 289-90. doi: 10.1038/225289a0

MARTINI, E. \& MÜLLER, C. (1986): Current Tertiary and Quaternary calcareous nannoplankton stratigraphy and correlations.- Newslett. Stratigr., 16/2, 99-112. doi: $10.1127 /$ nos $/ 16 / 1986 / 99$

MELINTE, C.M. (2004): Calcareous Nannoplankton, a Tool to Assign Environmental Changes.- Article in Geo-Eco-Marina, doi: 10.5281/zenodo.57517

PERCH-NIELSEN, K. (1985a): Mesozoic calcareous nannofossils.- In: BOLLI, H.M., SAUNDERS, J.B. \& PERCH-NIELSEN, K. (eds.): Plankton Stratigraphy Volume 1. Cambridge University Press, Cambridge, 329-426.

PERCH-NIELSEN, K. (1985b): Cenozoic calcareous nannofossils.- In: BOLLI, H.M., SAUNDERS, J.B. \& PERCH-NIELSEN, K. (eds.): Plankton stratigraphy.-Cambridge University Press, 427-554

POISSON, A., YAĞMURLU, F., BOZCU, M. \& SENTÜRK, M. (2003): New insights on the tectonic setting and evolution around the apex of the Isparta Angle (SW Turkey).- Geological Journal, 38/3-4, 257-282. doi: 10.1002/gj.955

ROBERTSON, A.H.F., POISSON, A. \& AKINCI, O. (2003): Developments in research concerning Mesozoic-Tertiary Tethys and Neotectonics in the Isparta Angle, SW Turkey.- Geological Journal, 38/3-4, 195-234. doi: 10.1002/gj.953

SAGULAR, E.K. (2003a): Nannofosil verilerinin stratigrafik yaş ve ortamsal yorumlarda kullanımına ilișkin yeni bir inceleme yöntemi [A new determination method on using nannofossil data in stratigraphic ageing and paleoenvironmental analyses - in Turkish, with an English Abstract].- Suleyman Demirel University Journal of Science Institute, Special Issue, 7/2, 25-36.

SAGULAR, E.K. (2003b): Denizel kırıntılı kayaçlarda, eșyaşlı veya yeniden çökelimin nannofosil tanımlamalarına dayanan sayısal analizi [Discriminate analysis of synsedimentation or reworking in marine clastic sedimentary rocks based on nannofossil determinations - in Turkish, with an English Abstract].- Turkish Association Petroleum Geologists Bulletin, 15/2, 75-107.

\section{LIST OF CALCAREOUS NANNOFOSSIL TAXA}

Miocene Nannofossil Taxa:

Coccolithus miopelagicus BUKRY

Cyclicargolithus abisectus (MÜLLER) WISE

Cyclicargolithus floridanus (ROTH \& HAY) BUKRY

Discoaster druggii BRAMLETTE \& WILCOXON

Reticulofenestra bisecta (HAY, MOHLER \& WADE) ROTH

Reticulofenestra haqii BACKMAN

Reticulofenestra minuta ROTH

Reticulofenestra producta (KAMPTNER) WEI \& THIERSTEIN

Reticulofenestra pseudoumbilicus (GARTNER) GARTNER

Sphenolithus belemnos BRAMLETTE \& WILCOXON

Sphenolithus compactus BACKMAN

Sphenolithus conicus BUKRY

Sphenolithus disbelemnos FORNACIARI \& RIO

Sphenolithus dissimilis BUKRY \& PERCIVAL

Sphenolithus moriformis (BRONNIMANN \& STRADNER)

BRAMLETTE \& WILCOXON

Thoracosphaera heimii (LOHMANN) KAMPTNER

Triquetrorhabdulus carinatus MARTINI

Triquetrorhabdulus challengeri PERCH-NIELSEN

\section{Palaeogene Nannofossil Taxa:}

Blackites inversus (BUKRY \& BRAMLETTE) BOWN \& NEWSAM

Chiasmolithus gigas (BRAMLETTE \& SULLIVAN) RADOMSKI

Chiasmolithus solitus (BRAMLETTE AND SULLIVAN) LOCKER

Coccolithus eopelagicus (BRAMLETTE \& RIEDEL) BRAMLETTE \& SULLIVAN

Coccolithus formosus (KAMPTNER) WISE
ŞENEL, M. (1997): 1:100000 ölçekli Türkiye Jeoloji Haritaları No: 13, Isparta-J10 paftası [in Turkish].- Publication of Mineral Research and Exploration Institute, Department of Geological Research, Ankara, Turkey, 26 p.

VAN NAME, W.G. (1945): The North and South American ascidians.- Bull. Am. Mus. Nat. Hist., 84, 1-476.

WADE, B.S. \& BOWN, P.R (2006): Calcareous nannofossils in extreme environments: The 1352 Messinian Salinity Crisis. Polemi Basin, Cyprus.- Palaeogeogr. Palaeoclimatol. 1353 Palaeoecol., 233/3-4, 271-286. doi: 10.1016/j.palaeo.2005.10.007

WEI, W. \& WISE, S.W.JR. (1990): Biogeographic gradients of middle Eocene-Oligocene calcareous nannoplankton in the South Atlantic Ocean.- Palaeogeogr. Palaeoclimatol. Palaeoecol., 79/1-2, 29-61.

YAĞMURLU, F. (1994): Isparta güneyinde yeralan Tersiyer yaşlı türbiditik birimlerin fasiyes özellikleri [in Turkish].- Geosound, 24, 17-28.

YAVUZLAR, G. (2015): Burdur ve Isparta Arasında Bulunan Geç Tersiyer Denizel Tortul Kayaçlarının Nannofosillerle Krono-Biyostratigrafik Ç̈zümlenmesi [Chronobiostratigraphical analysis based on nannofossils of Late Tertiary Marine Sedimentary Rocks Located Between Burdur and Isparta - in Turkish, with an English Abstract].- Süleyman Demirel University, Natural and Applied Sciences Institute, Master Thesis, $102 \mathrm{p}$.

YAVUZLAR, G. \& SAGULAR, E.K. (2017): Burdur ve Isparta Arasında Bulunan Üst Tersiyer Denizel Tortul Kayaçlarının Nannofosillerle Biyostratigrafik Çözümlenmesi [Biostratigraphical analysis based on nannofossils of Upper Tertiary marine sedimentary rocks located between Burdur and Isparta - in Turkish, with an English Abstract].- Suleyman Demirel University, Journal of Natural and Applied Sciences, Volume 21, Issue 1, 79-87.

YOUNG, J.R. (1998): Neogene.- In: BOWN, P.R. (ed.): Calcareous nannofossil biostratigraphy. Kluwer Academic Publications, Dordrecht, 225-265. doi: 10.1007/97894-011-4902-0 8

YOUNG, J.R, BOWN, P.R. \& LEES, J.A. (2013): Nannotax Website.- International Nannoplankton Association (2013).

Coccolithus pelagicus (WALLICH) SCHILLER

Discoaster barbadiensis TAN

Discoaster deflandrei BRAMLETTE \& RIEDEL

Discoaster kuepperi STRADNER

Discoaster lodoensis BRAMLETTE \& RIEDEL

Discoaster mohleri BRAMLETTE \& PERCIVAL

Ericsonia robusta (BRAMLETTE \& SULLIVAN) EDWARDS $\&$ PERCH-NIELSEN

Discoaster saipanensis BRAMLETTE \& RIEDEL

Ericsonia subpertusa HAY \& MOHLER

Reticulofenestra dictyoda (DEFLANDRE IN DEFLANDRE \& FERT) STRADNER

Reticulofenestra gelida (GEITZENAUER) BACKMAN

Reticulofenestra hesslandii (HAQ) ROTH

Sphenolithus moriformis (BRONNIMANN \& STRADNER)

BRAMLETTE \& WILCOXON

Sphenolithus radians DEFLANDRE

Sphenolithus spiniger BUKRY

Thoracosphaera heimii (LOHMANN) KAMPTNER

Thoracosphaera saxea STRADNER

Zygrhablithus bijugatus (DEFLANDRE) DEFLANDRE_

\section{Mesozoic Nannofossil Taxa:}

Calculites obscurus (DEFLANDRE) PRINS \& SISSINGH IN SISSINGH

Lucianorhabdus cayeuxii DEFLANDRE

Micula VEKSHINA

Micula murus (MARTINI) BUKRY

Micula staurophora (GARDET) STRADNER

Thoracosphaera heimii (LOHMANN) KAMPTNER

Watznaueria barnesiae (BLACK) PERCH-NIELSEN 